\title{
AL-QUR'AN DAN PEMBINAAN KARAKTER SISWA MADRASAH IBTIDAIYAH
}

\author{
Heri Khoiruddin ${ }^{1}$, Hilman Mangkuwibawa ${ }^{2}$ \\ ${ }^{1,2}$ Fakultas Tarbiyah dan Keguruan, UIN Sunan Gunung Djati, Bandung, Indonesia \\ herikhoiruddin@uinsgd.ac.id
}

Naskah diterima:08 Januari, 2020, direvisi: 05 Februari, 2021, diterbitkan: 31 Maret, 2021

\begin{abstract}
The curriculum implemented in Elementary School /Madrasah Ibtidaiyah (MI) aims to prepare students to have the ability to live as individuals and citizens who are faithful, productive, creative, innovative, and effective and can contribute to the life of society, nation, state, and world civilization, through four competencies, namely the spiritual quotient, social skill, thinking skill and hard skill. Thereby, understanding the character building of MI students can be done through al-Qur'an learning in madrasah. This paper aims to find out the surahs and verses taught to students and how valuable this surah for students. The method used in this research was the library research method with a qualitative approach about the letters and verses of the Qur'an and then analyzed to determine its content. The analysis of these surahs and verses gives the conclusion that the first pillars of character instilled in Madrasah Ibtidaiyah students are faith and monotheism. The selected surahs totaled 22 which is al-Fatihah surah and 21 short surah in juz 30. These surahs content are complete including the principle of monotheism, examples of monotheistic, examples of deviates behavior from the values of monotheism, the reward for monotheism, and torment for ignoring faith and monotheism in life.
\end{abstract}

Keywords: Character building; Madrasah Ibtidaiyah; Religious education; Spiritual Quotient

\section{ABSTRAK}

Kurikulum yang berlaku di Sekolah Dasar/Madrasah Ibtidaiyah (MI) bertujuan mempersiapkan siswa memiliki kemampuan hidup sebagai pribadi yang beriman, produktif, kreatif, inovatif, dan afektif serta mampu berkontribusi pada kehidupan bermasyarakat, berbangsa, bernegara, dan peradaban dunia, melalui empat kompetensi, yaitu kompetensi spiritual, sosial, pengetahuan, dan keterampilan. Memahami pembinaan karakter siswa MI dapat ditelusuri dari pembelajaran al-Qur'an yang diajarkan di madrasah. Surat dan ayat-ayat tersebut adalah pondasi dan warna karakter yang ditanamkan oleh para guru pada siswa mereka. Tulisan ini bertujuan untuk mengetahui surat dan ayat-ayat apa saja yang diajarkan dan bagaimana nilai-nilai pada surat-surat tersebut ditanamkan pada siswa. Metode dalam penulisan ini menggunakan library research (studi kepustakaan) dengan pendekatan kualitatif dalam bentuk analisis konten (content analysis) terhadap surat dan ayat-ayat al-Qur'an yang kemudian dianalisis untuk mengetahui isi dan kandungannya. Diperoleh kesimpulan bahwa pilar karakter pertama yang ditanamkan pada siswa MI adalah keimanan dan ketauhidan. Untuk menyampaikan nilai-nilai keimanan dan ketauhidan pada siswa MI, terdapat dalam surat-surat terpilih yang berjumlah 22 surat, yaitu surat al-Fatihah dan 21 surat-surat pendek pada juz 30, yang isi dan kandungannya lengkap mulai dari prinsip ketauhidan, contoh perilaku tauhid dan perilaku yang menyimpang dari nilai-nilai ketauhidan, pahala karena bertauhid dan siksa karena mengabaikan keimanan dan ketauhidan dalam kehidupan.

Kata Kunci: Pendidikan karakter; Madrasah Ibtidaiyah; Pendidikan agama; Kecerdasan agama

\section{Pendahuluan}

Seiring dengan perkembangan teknologi, siswa saat ini tidak hanya belajar melalui lembaga formal seperti madrasah, tetapi juga melalui berbagai media sosial. Media sosial 
menjadi media yang sangat tidak terkendali untuk mengenalkan siswa berbagai perilaku, apakah perilaku baik ataupun perilaku buruk, apakah perilaku yang seiring dengan norma masyarakat ataupun perilaku yang bertentangan dengan norma masyarakat. Perkelahian, pornografi, kekerasan kepada sesama dan lainnya, semua sangat mudah untuk diakses melalui media sosial.

Pemerintah melalui permendikbud no 67 tahun 2013 tentang Kerangka Dasar dan Struktur Kurikulum Sekolah Dasar/Madrasah Ibtidaiyah menuntut adanya penanaman karakter mulai sejak anak masuk Sekolah Dasar/Madrasah Ibtidaiyah. Didasarkan pada permendikbud di atas, kurikulum yang diberlakukan di Sekolah Dasar/Madrasah Ibtidaiyah bertujuan untuk mempersiapkan para siswa untuk memiliki kemampuan hidup sebagai pribadi dan warga negara yang beriman, produktif, kreatif, inovatif, dan afektif serta mampu berkontribusi pada kehidupan bermasyarakat, berbangsa, bernegara, dan peradaban dunia, melalui empat kompetensi inti, yaitu kompetensi inti sikap spiritual, kompetensi inti sikap sosial, kompetensi inti pengetahuan, dan kompetensi inti keterampilan.

Berbagai penelitian terkait pendidikan karakter telah banyak dilakukan, sebut saja misalnya, "Pendidikan Karakter Berspektif Islam" yang ditulis Aan Hasanah (2012), "Keluarga Berbasis Karakter, Studi tentang Model Pendidikan Karakter dalam Keluarga" yang ditulis Amirullah (2015). Kemudian tulisan terkait pendidikan karakter di Madrasah Ibtidaiyah, ditulis di antaranya oleh Muhammad Afandi (2016) dengan judul "Character Education Investment in SD/MI", Hamdi Abdul Karim (2016) dengan judul "Pendidikan Karakter di Madrasah Ibtidaiyah", Asep Ediana Latip (2013) dengan judul "Pembelajaran Berbasis Karakter di Madrasah Ibtidaiyah".

Dalam buku yang ditulis Aan Hasanah (2012), tingkat keberhasilan pendidikan karakter dapat dilihat dari enam indikator pilar pendidikan, yaitu keimanan, kewarganegaraan, kepedulian, kejujuran, keberanian, dan tanggung jawab. Berdasarkan enam pilar di atas, keimanan menjadi pilar pertama dan utama yang harus dimiliki para siswa Madrasah Ibtidaiyah. Dan keimanan yang dimaksud dalam pendidikan Islam adalah ketauhidan disertai dengan berbagai perilaku sehari-hari yang menggambarkan nilai-nilai ketauhidan kepada Allah Swt.

Dalam Islam, pondasi pertama pendidikan karakter dilakukan ketika anak masih dalam kandungan. Pendidikan karakter pada anak kemudian diperkuat dalam keluarga, lingkungan, dan berikutnya melalui pendidikan formal di Madrasah. Tahapan berjenjang pembinaan karakter di Madrasah Ibtidaiyah menjadi tahapan pertama pendidikan karakter melalui pendidikan formal. Sebagian anak mungkin sudah melalui pembinaan karakter melalui Pendidikan Anak Usia Dini atau Taman Kanak-kanak, tetapi sebagian lain mungkin tidak melaluinya. Semua komponen dalam proses pendidikan anak menjadi sangat berpengaruh dan saling terkait untuk terbinanya karakter yang kuat dan baik.

Al-Qur'an sebagai sumber utama pembinaan karakter siswa dalam pendidikan Islam di Indonesia telah diajarkan kepada siswa mulai kelas 1 Madrasah Ibtidaiyah. Pemerintah melalui permendikbud no 67 tahun 2013 tentang Kerangka Dasar dan Struktur Kurikulum Sekolah Dasar/Madrasah Ibtidaiyah, telah mengalokasikan pembelajaran al-Qur'an di Madrasah Ibtidaiyah dengan alokasi 2 jam pelajaran per minggu. Alokasi ini lebih banyak dari yang diajarkan di Sekolah Dasar yang hanya mencantumkan pembelajaran al-Qur'an sebagai bagian dari mata pelajaran Pendidikan Agama Islam.

Surat al-Qur'an sebagai salah satu materi pembelajaran yang diajarkan, telah diajarkan mulai kelas 1 sampai 6 di Madrasah Ibtidaiyah berjumlah 22 surat, yaitu surat alFatihah dan 21 surat yang ada pada juz 30. Ke 22 surat yang diajarkan didominasi suratsurat makkiyah, atau surat yang diturunkan di Mekah. Surat pada juz 30 adalah surat-surat 
yang pendek, yang secara khusus diwahyukan kepada Rasulullah Saw sebagai bagian dari bagaimana Allah membina karakter beliau untuk menjalani dakwah dan kehidupannya sehari-hari. Pola yang dibangun oleh para guru untuk membina karakter para siswanya melalui interaksi yang berkelanjutan dengan surat-surat di atas menjadi penting untuk ditelusuri. Mulai dari membaca, menghafal, menerjemahkan dan memahami.

\section{Metodologi}

Metode dalam penulisan ini adalah menggunakan metode library research (studi kepustakaan) dengan pendekatan kualitatif dalam bentuk analisis konten (content analysis) terhadap surat dan ayat-ayat yang diajarkan oleh guru kepada siswa mulai kelas 1 sampai 6 Madrasah Ibtidaiyah. Analisis surat dan ayat-ayat ini menarik untuk dilakukan karena hasil dari analisis ini akan memberikan gambaran apa saja nilai-nilai yang diajarkan pada siswa kelas 1 sampai 6, apa yang dominan diajarkan kepada para siswa, dan bagaimana tahapan nilai-nilai tersebut diajarkan kepada mereka. Masing-masing surat pada setiap kelas dianalisis didasarkan pada isi dan kandungannya secara tekstual, bagaimana sebab turunnya, dan apa saja nilai-nilai yang dapat diajarkan kepada para siswa sebagai bagian dari upaya yang dapat dilakukan agar para siswa memiliki karakter yang kuat berbasis nilai-nilai ajaran al-Qur'an.

\section{Hasil dan Pembahasan}

3.1 Pembinaan Karakter Siswa Kelas 1 Madrasah Ibtidaiyah

Surat al-Qur'an yang diajarkan di kelas 1 Madrasah Ibtidaiyah berjumlah 7 surat. 5 surat diajarkan pada semester ganjil, yaitu surat al-Fatihah, an-Nas, al-Falaq, al-Ikhlash dan al-Lahab. 2 surat diajarkan pada semester genap, yaitu surat an-Nashr dan al-Quraish. Pembinaan karakter pada kelas 1 sesuai dengan kompetensi dasar yang ditentukan adalah dengan mengenal, mampu membacanya dan menghafalnya dengan baik.

Ketujuh surat ini didominasi oleh ajaran-ajaran keimanan dan ketauhidan. Surat alFatihah adalah surat yang pertama dalam susunan tertib mushhaf. Kandungan surat ini terkait kewajiban yang dipenuhi oleh setiap manusia kepada Allah, yaitu menyembah-Nya dan tidak memohon pertolongan kecuali hanya kepada-Nya. Dalam surat ini juga, dikenalkan adanya tiga jalan yang ditempuh oleh manusia, yaitu jalan yang penuh nikmat, jalan yang penuh murka, dan jalan yang sesat.

Analisis menarik terkait kandungan surat ini dikemukakan oleh Abduh dan Quraish Shihab. Surat ini turun menguraikan lima persoalan, yaitu (a) tauhid; (b) janji dan ancaman; (c) ibadah yang menghidupkan tauhid; (d) penjelasan tentang jalan kebahagiaan di dunia dan di akhirat dan cara mencapainya; (e) pemberiataan atau kisah generasi terdahulu. Persoalan tauhid didapat pada ayat kedua dan kelima; persoalan janji dan ancaman didapat pada ayat pertama, ketiga dan ketujuh; persoalan ibadah didapat pada ayat kelima dan ketujuh; dan persoalan sejarah masa lalu didapat pada ayat terakhir (Shihab, 2010:5).

Surat an-Nas adalah surat terakhir atau ke-114 berdasarkan tertib mushhaf. Kandungan surat ini terkait keharusan untuk memohon perlindungan hanya kepada Allah. Kata an-Nas sebagai nama untuk ayat ini disebutkan sebanyak 241 dalam al-Qur'an. Kata an-Nas berarti kelompok manusia dan digunakan al-Qur'an dalam arti jenis manusia atau sekelompok tertentu dari manusia (Shihab, 2008:640).

Surat an-Nas terdiri dari 6 ayat. Kandungan surat ini terkait pengenalan Allah sebagai yang memelihara manusia, yang menguasai manusia, dan yang melindungi manusia dari berbagai bisikan yang menyebabkan manusia terjerumus kepada kerusakan. Terkait kata anNas yang disebutkan tiga kali, ulama berbeda dalam memahaminya. Quraish Shihab dalam 
tafsirnya (2008:640) menghimpun dua pendapat, yaitu: (a) tiga kali kata an-Nas memiliki tiga pengertian. Kata an-Nas pertama adalah janin dan anak kecil karena mereka membutuhkan perlindungan. Kata an-Nas kedua adalah orang dewasa yang membutuhkan bimbingan dan penguasaan. Kata an-Nas ketiga adalah orang tua yang sangat membutuhkan kedekatan dan kepatuhan kepada Allah; (b) tiga kali kata an-Nas mengandung makna yang sama yakni untuk seluruh manusia tanpa kecuali.

Surat al-Falaq adalah surat ke-113 berdasarkan tertib mushhaf. Sesuai dengan kandungan surat an-Nas, surat ini pun terkait keharusan untuk memohon perlindungan hanya kepada Allah. Surat al-Falaq dan an-Nas dinamakan juga dengan surat al-Muawwadzataini yang berarti dua surat yang menuntun pembacanya kepada tempat perlindungan atau memasukkannya ke dalam arena yang dilindungi (Shihab, 2008:620). Surat ini terdiri dari 5 ayat. Dalam surat ini dikenalkan berbagai kejahatan yang berpotensi mengganggu manusia, yaitu: (a) kejahatan yang diciptakan; (b) kejahatan malam saat ia gelap gulita; (c) kejahatan peniup-peniup pada buhul-buhul; (d) kejahatan pengiri jika ia iri.

Surat al-Ikhlash adalah surat ke-112 berdasarkan tertib mushhaf. Surat ini terdiri dari dari 4 ayat. Kandungan surat ini terkait keimanan dan ketauhidan. Dalam surat ini ditegaskan bahwa Allah adalah Esa, tempat bergantung semua makhluk, tidak memiliki anak dan tidak diperanakkan, dan tidak ada yang setara dengan-Nya.

Dua surat berikutnya yang diajarkan kepada siswa kelas 1 adalah dua surat yang berisi balasan yang perbuatan jahat dan balasan bagi perbuatan baik. Surat al-Lahab adalah surat ke-111 berdasarkan tertib mushhaf. Surat ini terdiri dari 5 ayat. Kandungan surat ini terkait upaya yang dilakukan oleh Abu Lahab untuk menghalang-halangi Nabi untuk berdakwah menyampaikan kebenaran. Dalam ayat ini juga disinggung, bahwa siapapun yang menghalangi orang lain untuk berbuat baik, maka baginya balasan di akhirat. Surat anNashr adalah surat ke-110 berdasarkan tertib mushhaf. Surat ini terdiri dari 3 ayat. Kandungan surat ini terkait janji Allah kepada mereka yang berpegang pada kebenaran. Dalam surat ini disinggung di antara buah pertolongan dan kemenangan, yaitu berbondongbondongnya orang untuk masuk Islam.

Surat yang terakhir diajarkan di kelas 1 adalah surat al-Quraish. Surat ini tidak ditempatkan langsung dalam tertib mushhaf sebelum surat al-Nashr. Surat al-Quraish adalah surat ke-106 berdasarkan tertib mushhaf. Surat ini terdiri dari 4 ayat. Kandungan surat ini terkait kebiasaan masyarakat Quraish yang suka berdagang dan mendapatkan keuntungan berlimpah dari dagangannya, tetapi mereka abai untuk mensyukuri nikmat tersebut dan abai untuk mengesakan Allah yang telah memberi mereka berbagai keuntungan dalam perniagaan mereka. Kandungan surat ini mengingatkan mereka untuk bersyukur dan bertauhid.

\subsection{Pembinaan Karakter Siswa Kelas 2 Madrasah Ibtidaiyah}

Surat al-Qur'an yang diajarkan di kelas 2 Madrasah Ibtidaiyah berjumlah 6 surat. 2 surat diajarkan pada semester ganjil, yaitu surat al-Kautsar dan al-Kafirun. 4 surat diajarkan pada semester genap, yaitu surat al-Ma'un, al-Fil, al-'Ashr dan al-Qadr. Sesuai dengan pembinaan karakter pada kelas 1, pembinaan karakter pada kelas 2 pun pengenalan, bacaan, dan hafalan.

Keenam surat ini didominasi oleh ajaran-ajaran keimanan dan ketauhidan dengan rincian yang berbeda dari kelas sebelumnya. Tiga surat ditempatkan langsung dalam tertib mushhaf secara berurutan, dan tiga lainnya tidak. Surat al-Kautsar adalah surat ke- 108 berdasarkan tertib mushhaf. Surat ini terdiri dari 3 ayat. Kandungan surat ini terkait tandatanda bagaimana seseorang bersyukur atas nikmat yang telah diberikan, yaitu shalat dan 
berkurban. Surat al-Kafirun adalah surat ke- 109 berdasarkan tertib mushhaf. Surat ini terdiri dari 6 ayat. Kandungan surat ini terkait keteguhan dan keikhlasan untuk tetap bertauhid kepada Allah dan mengabaikan godaan kemewahan materi dunia yang ditawarkan. Sebab turun surat ini terkait upaya masyarakat Quraish ketika itu yang berusaha mempengaruhi Rasulullah Saw dengan menawarkan harta kekayaan agar menjadi orang yang paling kaya di kota Mekah dan akan dinikahkan dengan siapa saja yang beliau kehendaki, hingga kemudian turunlah surat di atas yang menegaskan keteguhan Rasulullah Saw atas semua tawaran yang diterimanya (al-Wahidi, 2004:310). Surat al-Ma'un adalah surat ke-107 berdasarkan tertib mushhaf. Surat ini terdiri dari 7 ayat. Kandungan surat ini terkait diantara contoh keimanan dalam kehidupan sehari-hari, yaitu untuk beribadah dan berbagi dengan sesama karena Allah dan bukan karena yang lainnya. Sebab turun surat ini terkait kaum munafiqin yang mempertontonkan shalat kepada kaum mukminin dengan ria dan meninggalkan shalat ketika tidak ada yang melihatnya (al-Wahidi, 2004:307).

Tiga surat lainnya yang diajarkan di kelas 2 adalah surat al-Fil, al-'Ashr, dan al-Qadr. Surat al-Fil adalah surat ke-105 berdasarkan tertib mushhaf. Surat ini terdiri dari 5 ayat. Kandungan surat ini terkait pertolongan Allah dan kegagalan orang-orang yang hendak menghancurkan ka'bah. Surat al-'Ashr adalah surat ke-103 berdasarkan tertib mushhaf. Surat ini terdiri dari 3 ayat. Kandungan surat ini terkait keharusan untuk memperhatikan waktu. Dalam surat ini ditegaskan, bahwa banyak orang merugi dan menyesal karena tidak memanfaatkan waktu dengan baik. Surat al-Qadr adalah surat ke-97 berdasarkan tertib mushhaf. Surat ini terdiri dari 5 ayat. Kandungan surat ini terkait malam diturunkannya alQur'an, yaitu malam lailat al-qadar. Malam lailat al-qadar adalah salah satu malam yang harus dimanfaatkan untuk kebaikan karena di dalamnya terdapat banyak kesejahteraan sampai terbit fajar.

\subsection{Pembinaan Karakter Siswa Kelas 3 Madrasah Ibtidaiyah}

Surat al-Qur'an yang diajarkan di kelas 3 Madrasah Ibtidaiyah berjumlah 7 surat. 3 surat diajarkan pada semester ganjil, yaitu surat al-Humazah, at-Takatsur, dan al-Zalzalah. 4 surat diajarkan pada semester genap, yaitu surat al-Qari'ah, at-Tin, al-Fatihah dan alIkhlash.

Pembinaan karakter pada kelas 3 sesuai dengan kompetensi dasar yang ditentukan adalah dengan mengenal, mampu membacanya, menghafalnya, menerjemahkannya, dan memahami kandungannya. Pada kelas 3 ini, pembinaan melalui pemahaman disertai dengan berbagai contoh untuk diterapkan dalam kehidupan sehari-hari.

Ketujuh surat ini didominasi oleh ajaran-ajaran keimanan dan ketauhidan dengan rincian yang berbeda dari surat-surat sebelumnya. Dari ketujuh surat ini, 2 surat sudah diajarkan pada kelas sebelumnya, yaitu surat al-Fatihah dan al-Ikhlash, dan 5 surat lainnya adalah surat yang diajarkan di kelas 3 .

Kelima surat yang diajarkan tidak ditempatkan langsung dalam tertib mushhaf secara berurutan. Dua dari lima surat ini mengingatkan akan ancaman dan siksa bagi mereka yang lupa diri dan sombong karena kekayaan yang dimilikinya, yaitu surat al-Humazah dan atTakatsur. Surat al-Humazah adalah surat ke-104 berdasarkan tertib mushhaf. Surat ini terdiri dari 9 ayat. Kandungan surat ini terkait ancaman dan kecelakaan bagi orang-orang yang menimbun harta dan tidak menafkahkannya di jalan Allah. Sebab turun ayat ini terkait Ubay ibn Khalaf, seorang kaya raya yang selalu menghina dan mengejek karena kekayaan yang dimilikinya (al-Wahidi, 2004:305). Surat at-Takatsur adalah surat ke-102 berdasarkan tertib mushhaf. Surat ini terdiri dari 8 ayat. Senada dengan surat al-Humazah, surat ini terkait 
kesombongan yang melanda orang-orang ketika itu, karena memiliki kekayaan yang berlimpah.

Dua surat lainnya berbicara tentang hari kiamat, yaitu surat al-Zalzalah dan alQari'ah. Surat al-Zalzalah adalah surat ke-99 berdasarkan tertib mushhaf. Surat ini terdiri dari 8 ayat. Kandungan surat ini terkait tanda terjadinya hari kiamat dan apa yang dialami oleh manusia ketika itu. Ketika turun ayat 8 dari surat ini, kaum muslimin beranggapan bahwa orang yang sedekahnya sedikit tidak akan memperoleh pahala, demikian juga dengan orang yang berbuat dosa kecil seperti mencela dan lainnya tidaklah tercela dan menganggap bahwa ancaman neraka hanya diperuntukkan bagi yang melakukan dosa besar (al-Wahidi, 2004:300). Dalam surat ini ditegaskan, bahwa setiap manusia akan mendapatkan balasan dari apa yang dilakukannya, apakah balasan untuk perbuatan baik ataupun untuk perbuatan buruk yang telah dilakukannya.

Surat al-Qari'ah adalah surat ke-101 berdasarkan tertib mushhaf. Surat ini terdiri dari 11 ayat. Senada dengan surat al-Zalzalah, kandungan surat ini terkait tanda terjadinya hari kiamat. Dalam surat ini ditegaskan, bahwa mereka yang timbangannya kebaikannya lebih berat maka akan mendapatkan kehidupan yang membahagiakan, dan bagi mereka yang timbangan keburukannya lebih berat maka akan mendapatkan kehidupan yang menyengsarakan di api neraka.

Surat terakhir yang diajarkan di kelas 3 adalah surat at-Tin. Surat at-Tin adalah surat ke-95 berdasarkan tertib mushhaf. Surat ini terdiri dari 8 ayat. Kandungan surat ini terkait sumpah yang diberikan oleh Allah bahwa manusia berada dalam kerugian, kecuali mereka beriman dan beramal shalih, maka bagi mereka adalah kebahagiaan.

\subsection{Pembinaan Karakter Siswa Kelas 4 Madrasah Ibtidaiyah}

Surat al-Qur'an yang diajarkan di kelas 4 Madrasah Ibtidaiyah berjumlah 5 surat. 3 surat diajarkan pada semester ganjil, yaitu surat an-Nashr, al-Kautsar dan al-'Adiyah. 2 surat diajarkan pada semester genap, yaitu surat al-Lahab dan al-Insyirah. Sesuai dengan kelas sebelumnya, pada kelas 4 ini, pembinaan didasarkan pada bacaan, hafalan, terjemahan dan pemahaman kandungan surat. Dari kelima surat ini, 3 surat sudah diajarkan pada kelas sebelumnya, yaitu surat an-Nashr, al-Kautsar dan al-Lahab.

Dua surat yang belum diajarkan di kelas sebelumnya dan diajarkan di kelas 4 adalah surat al-'Adiyah dan al-Insyirah. Surat al-'Adiyah adalah surat ke-100 berdasarkan tertib mushhaf. Surat ini terdiri dari 11 ayat. Kandungan surat ini terkait sifat manusia yang cenderung kikir karena kecintaan mereka yang berlebihan kepada harta. Dalam surat ini ditegaskan bahwa kekikirannya akan dibalas pada hari kiamat. Surat al-Insyirah adalah surat ke-94 berdasarkan tertib mushhaf. Surat ini terdiri dari 8 ayat. Kandungan surat ini terkait keharusan bagi setiap orang untuk berjuang di jalan Allah dengan ikhlash. Dalam surat ini ditegaskan bahwa setiap orang yang berjuang berpotensi bertemu dengan berbagai kesulitan, tetapi jika berharap kepada Allah, maka kesulitan itu hilang, karena Allah senantiasa memberi berbagai kemudahan untuk setiap kesulitan yang dihadapi oleh manusia.

\subsection{Pembinaan Karakter Siswa Kelas 5 Madrasah Ibtidaiyah}

Surat al-Qur'an yang diajarkan di kelas 5 Madrasah Ibtidaiyah berjumlah 5 surat. 3 surat diajarkan pada semester ganjil, yaitu surat al-Kafirun, al-Ma'un dan at-Takatsur. 2 surat didasarkan pada bacaan, hafalan, terjemahan dan pemahaman kandungan surat dengan rincian yang berbeda dari dua kelas sebelumnya. Kelima surat yang diajarkan pada kelas ini adalah surat-surat yang sudah diajarkan pada kelas-kelas sebelumnya. 


\subsection{Pembinaan Karakter Siswa Kelas 6 Madrasah Ibtidaiyah}

Surat al-Qur'an yang diajarkan di kelas 6 Madrasah Ibtidaiyah berjumlah 2 surat, yaitu surat adl-Dluha pada semester ganjil dan surah al-Bayyinah pada semester genap. Sesuai dengan surat-surat sebelumnya, pembinaan pada kelas 6 hingga pemahaman kandungan dengan rincian yang berbeda. Surat adl-Dluha adalah surat ke-93 berdasarkan tertib mushhaf. Surat ini terdiri dari 11 ayat. Kandungan surat ini terkait beberapa nikmat yang Allah berikan yang seringkali diabaikan oleh manusia. Dalam surat ini ditegaskan, bahwa Allah tidak pernah meninggalkan orang-orang yang beriman, yaitu dengan cara: (a) Allah melindungi ketika lemah; (b) Allah memberikan petunjuk bingung; (c) Allah memberi kecukupan ketika kekurangan. Surat al-Bayyinah adalah surat ke-98 berdasarkan tertib mushhaf. Surat ini terdiri dari 8 ayat. Kandungan surat ini terkait sifat dan perilaku ahli kitab dan orang-orang musyrik yang meminta bukti untuk kebenaran yang dibawa oleh Rasulullah Saw, tetapi kemudian mengingkarinya ketika bukti itu ada di hadapan mereka.

Surat yang diajarkan dari kelas 1 sampai 6 tidaklah mengikuti susunan kronologis turunnya ataupun susunan tertib mushaf secara utuh. Hal ini dapat dilihat pada rincian surat di atas yang tidak mengikuti susunan turunnya ataupun susunan tertib mushaf. Pada kelas tertentu diajarkan mengikuti susunan tertentu dan pada kelas lainnya tidak, sebagaimana dapat dilihat dalam tabel berikut.

Tabel 1. Surat-surat yang diajarkan di Madrasah Ibtidaiyah

\begin{tabular}{|c|c|c|c|c|c|c|c|c|}
\hline \multicolumn{3}{|c|}{ Surat } & \multicolumn{6}{|c|}{ Kelas } \\
\hline No & Nama & Urutan & 12 & 3 & 4 & 5 & 6 & Jumlah \\
\hline 01 & al-Fatihah & 001 & $\sqrt{ }$ & $\sqrt{ }$ & & & & 2 \\
\hline 02 & an-Nas & 114 & $\sqrt{ }$ & & & & & 1 \\
\hline 03 & al-Falaq & 113 & $\sqrt{ }$ & & & & & 1 \\
\hline 04 & al-Ikhlash & 112 & $\sqrt{ }$ & $\sqrt{ }$ & & & & 2 \\
\hline 05 & al-Lahab & 111 & $\sqrt{ }$ & & $\sqrt{ }$ & & & 2 \\
\hline 06 & an-Nashr & 110 & $\sqrt{ }$ & & $\sqrt{ }$ & $\sqrt{ }$ & & 3 \\
\hline 07 & al-Kafirun & 109 & $\sqrt{ }$ & & & $\sqrt{ }$ & & 2 \\
\hline 08 & al-Kautsar & 108 & $\sqrt{ }$ & & $\sqrt{ }$ & & & 2 \\
\hline 09 & al-Ma'un & 107 & $\sqrt{ }$ & & & $\sqrt{ }$ & & 2 \\
\hline 10 & al-Quraish & 106 & $\sqrt{ }$ & & & $\sqrt{ }$ & & 2 \\
\hline 11 & al-Fil & 105 & $\sqrt{ }$ & & & & & 1 \\
\hline 12 & al-Humazah & 104 & & $\sqrt{ }$ & & & & 1 \\
\hline 13 & al-'Ashr & 103 & $\sqrt{ }$ & & & & & 1 \\
\hline 14 & al-Takatsur & 102 & & $\sqrt{ }$ & & $\sqrt{ }$ & & 2 \\
\hline 15 & al-Qari'ah & 101 & & $\sqrt{ }$ & & & & 1 \\
\hline 16 & al-`Adiyah & 100 & & & $\sqrt{ }$ & & & 1 \\
\hline 17 & al-Zalzalah & 099 & & $\sqrt{ }$ & & & & 1 \\
\hline 18 & al-Bayyinah & 098 & & & & & $\sqrt{ }$ & 1 \\
\hline 19 & al-Qadr & 097 & $\sqrt{ }$ & & & & & 1 \\
\hline 20 & al-'Alaq & 096 & & & & & & 0 \\
\hline 21 & at-Tin & 095 & & $\sqrt{ }$ & & & & 1 \\
\hline 22 & al-Insyirah & 094 & & & $\sqrt{ }$ & & & 1 \\
\hline 23 & adl-Dluha & 093 & & & & & $\sqrt{ }$ & 1 \\
\hline
\end{tabular}


Berdasarkan bagan di atas, dari 23 surat sesuai urutan tertib mushhaf selain alFatihah, 1 surat tidak diajarkan yaitu surat al-'Alaq dan 1 surat diajarkan 3 kali, yaitu surat an-Nashr. Selain dari dua surat di atas, sebagian diajarkan 1 kali dan sebagian lainnya diajarkan 2 kali. Dengan kata lain, surat al-'Alaq sebagai surat yang pertama turun tidak diajarkan, dan janji Allah untuk memberikan kemenangan karena berprinsip pada kebenaran dan ketauhidan disampaikan hingga $3 \mathrm{kali}$, atau paling banyak di antara materi-materi ketauhidan lainnya.

\section{Kesimpulan}

Surat yang diajarkan pada kelas 1 sampai 6 Madrasah Ibtidaiyah berjumlah 22 surat. Kandungan surat ini umumnya terkait keimanan dan ketauhidan. Pilar pendidikan karakter yang ditanamkan kepada siswa Madrasah Ibtidaiyah diawali dengan ditanamkannya nilainilai ketauhidan sebagai pondasi dalam kehidupan sehari-hari. Dari surat-surat tersebut, diajarkan juga diantara perilaku yang baik sebagai salah satu cerminan berkarakternya seorang muslim, disertai juga contoh perilaku tidak baik, pahala karena melakukan kebaikan dan siksa karena melakukan keburukan.

\section{Daftar Pustaka}

Abdul Karim, Hamdi. Pendidikan Karakter di Madrasah Ibtidaiyah. Elementary, Vol 2, Edisi 2, Juli 2016, h. 45-56.

Afandi, Muhammad. Character Education Investment in SD/MI. Elementary, Vol 2, Edisi 2, Juli 2016, h. 14-25.

Al-Qur'an dan Terjemahnya. Kerajaan Saudi Arabia: Mujamma' al-Malik Fahd li Thiba'at al-Mushhaf, tt.

Al-Wahidi, Abu Hasan 'Ali ibn Ahmad. Asbab Nuzul al-Qur'an. Beirut: Dar al-Kutub al'Ilmiyah, 2004.

Amirulloh. Keluarga Berbasis Karakter, Studi tentang Model Pendidikan Karakter dalam Keluarga. Bandung: Fajar Media, 2015.

Hasanah, Aan. Pendidikan Karakter Berperspektif Islam. Bandung: Insan Komunika, 2012. Latip, Asep Ediana. Pembelajaran Berbasis Karakter di Madrasah Ibtidaiyah. MP, Vol XXVIII No.1, 2013, h. 40-58.

Permendikbud no 67 tahun 2013 tentang Kerangka Dasar dan Struktur Kurikulum Sekolah Dasar/Madrasah Ibtidaiyah.

Shihab, M. Quraish. Tafsir al-Mishbah Pesan, Kesan, dan Keserasian al-Qur'an. Volume 1. Jakarta: Lentera Hati, 2010.

Shihab, M. Quraish. Tafsir al-Mishbah Pesan, Kesan, dan Keserasian al-Qur'an. Volume 15. Jakarta: Lentera Hati, 2008 